\title{
PLT Neutral Beam Injection Systems
}
G. C. Barber
C. W. Blue
M. M. Menon
W. K. Dagenhart
R. E. Potter
P. M. Ryan
R. C. Davis
C. A. Foster
W. L. Gardner
H. H. Haselton
J. Kim
S. L. Milora
D. E. Schechter
S. W. Schwenterly
D. O. Sparks
W. L. Stirling
C. C. Tsai
J. H. Whealton
R. E. Wright 


\section{DISCLAIMER}

This report was prepared as an account of work sponsored by an agency of the United States Government. Neither the United States Government nor any agency Thereof, nor any of their employees, makes any warranty, express or implied, or assumes any legal liability or responsibility for the accuracy, completeness, or usefulness of any information, apparatus, product, or process disclosed, or represents that its use would not infringe privately owned rights. Reference herein to any specific commercial product, process, or service by trade name, trademark, manufacturer, or otherwise does not necessarily constitute or imply its endorsement, recommendation, or favoring by the United States Government or any agency thereof. The views and opinions of authors expressed herein do not necessarily state or reflect those of the United States Government or any agency thereof. 


\section{DISCLAIMER}

Portions of this document may be illegible in electronic image products. Images are produced from the best available original document. 


\section{Printed in the United States of America. Available from National Technical Information Service U.S. Department of Commerce 5285 Port Royal Road, Springfield, Virginia 22161}

Price: Printed Copy $\$ 4.50$; Microfiche $\$ 3.00$

This report was prepared as an account of work sponsored by an agency of the United States Government. Neither the United States Government nor any agency thereof, nor any of their employees, contractors, subcontractors, or their employees, makes any warranty, express or implied, nor assumes any legal liability or responsibility for any third party's use or the results of such use of any information, apparatus, product or process disclosed in this report, nor represents that its use by such third party would not infringe privately owned rights. 
ORNL/TM-6658

Dist. Category UC-20

Contract No. W-7405-eng-26

FUSION ENERGY DIVISION

PLT NEUTRAL BEAM INJECTION SYSTEMS

M. M. Menon
G. C. Barber
R. E. Potter
C. W. Blue
P. M. Ryan
W. K. Dagenhart
D. E. Schechter
R. C. Davis
S. W. Schwenterly
C. A. Foster
D. O. Sparks
W. L. Gardner
W. L. Stirling
H. H. Haselton
C. C. Tsai
J. Kim
J. H. Whealton
S. L. Milora
R. E. Wright

Date Published: January, 1979 This report was prepared as an account of work
sponsored by the United States Government. Neither the
United States nor the United States Department of
Energy, nor any of their employees, siun any of thefr
contractors, subcontractors, or their employees, makes
any warranty, express ot imptied, or assumes any legal
liability or responsibility for the accuracy. completeness
or usefulness of any information, apparatus, product or
process disclosed, or represents that its use would not
infringe privately owned nigh ls.

NOTICE This document contains information of a preliminary nature. It is subject to revision or correction and therefore does not represent a final report.

Prepared by the

OAK RIDGE NATIONAL LABORATORY
Oak Ridge, Tennessee 37830
operated by
UNION CARBIDE CORPORATION
for the
DEPARTMENT OF ENERGY


THIS PAGE

\section{WAS INTENTIONALLY LEFT BLANK}




\section{CONTENTS}

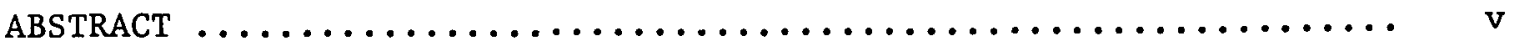

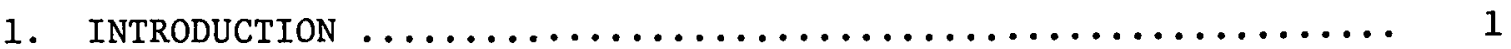

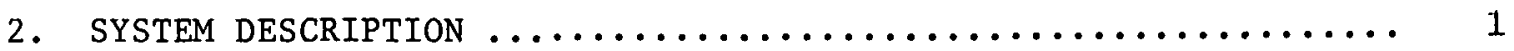

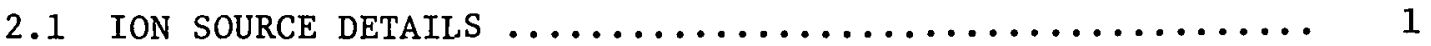

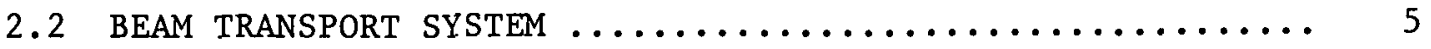

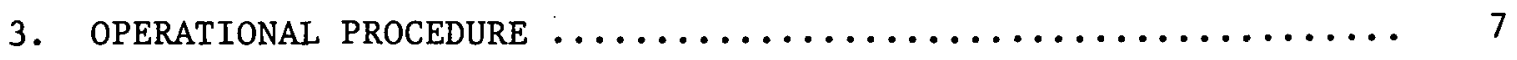

3.1 FILAMENT CONDITIONING $\ldots \ldots \ldots \ldots \ldots \ldots \ldots \ldots \ldots \ldots \ldots \ldots$

3.2 ARC DTSCHARGE CONDITIONING $\ldots \ldots \ldots \ldots \ldots \ldots \ldots \ldots \ldots \ldots$

3.3 EXTRACTION CONDITIONING $\ldots \ldots \ldots \ldots \ldots \ldots \ldots \ldots \ldots \ldots \ldots$

4. CHARACTERISTICS OF THE SYSTEM $\ldots \ldots \ldots \ldots \ldots \ldots \ldots \ldots \ldots \ldots \ldots \ldots$

5. TROUBLESHOOTING $\ldots \ldots \ldots \ldots \ldots \ldots \ldots \ldots \ldots \ldots \ldots \ldots \ldots \ldots \ldots \ldots$

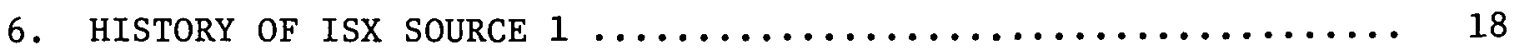

APPENDIX: COATINGS ON ALUMINUM RING $\ldots \ldots \ldots \ldots \ldots \ldots \ldots \ldots \ldots \ldots \ldots$ 


\section{THIS PAGE}

\section{WAS INTENTIONALLY \\ LEFT BLANK}


A brief description of the Princeton Large Torus (PLT) neutral beam injection system is given and its performance characteristics are outlined. A detailed operational procedure is included, as are some tips on troubleshooting. Proper operation of the source is shown to be a crucial factor in system performance. 


\section{INTRODUCTION}

A brief description of the Princeton Large Torus (PLT) neutral injection system is given and its performance characteristics are outlined. A detailed operational procedure is included to aid the user in obtaining the maximum power from the source. Some tips on troubleshooting are also included.

From our experience, we can say that the system can consistently deliver about $650 \mathrm{~kW}$ of neutrals with hydrogen and $750 \mathrm{~kW}$ with deuterium. If the source with shaped apertures is used, these values will be $750 \mathrm{~kW}$ and $850 \mathrm{~kW}$, respectively. A properly conditioned source would run with better than $80 \%$ reliability. At the higher power levels, $80-85 \%$ of the neutrals will belong to the primary energy species.

\section{SYSTEM DESCRIPTION}

The test facility, consisting of the source, the beam transport system, and the target chamber that substitutes for the tokamak, is shown in Fig. 2.1.

\subsection{ION SOURCE DETAILS}

Figure 2.2 shows the various elements of the ion source schematically. The type of source used is a modified duoPIGatron with a threegrid accel-decel extraction arrangement. The grids are curved with the convex surface towards the plasma to provide a focal length of $4 \mathrm{~m}$. Two types of apertures are used: (1) right circular apertures $3.8 \mathrm{~mm}$ in diameter, 1799 in number, providing a transparency of 53\%, and (2) shaped apertures, as shown in Fig. 2.3, 1799 in number, providing a transparency of $38 \%$. Other particulars of the grids are listed below.

\footnotetext{
Active grid diameter $=22 \mathrm{~cm}$

Grid thickness $=2 \mathrm{~mm}$

Accel gap $=6 \mathrm{~mm}$

Decel gap $=2 \mathrm{~mm}$
} 
ORNL DWG 76-12603

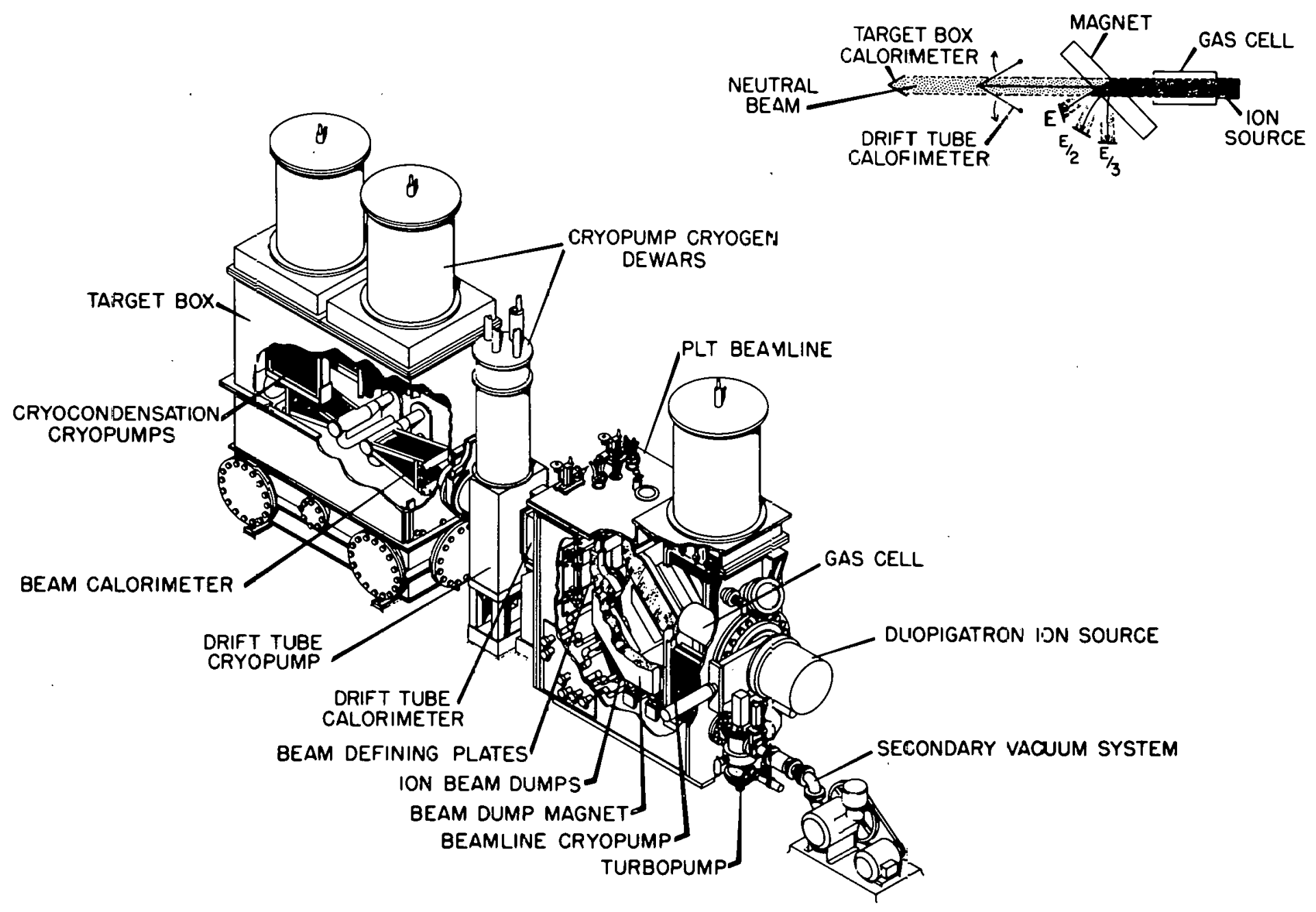

Fig. 2.1. ORNL/PLT beamline and target box. 


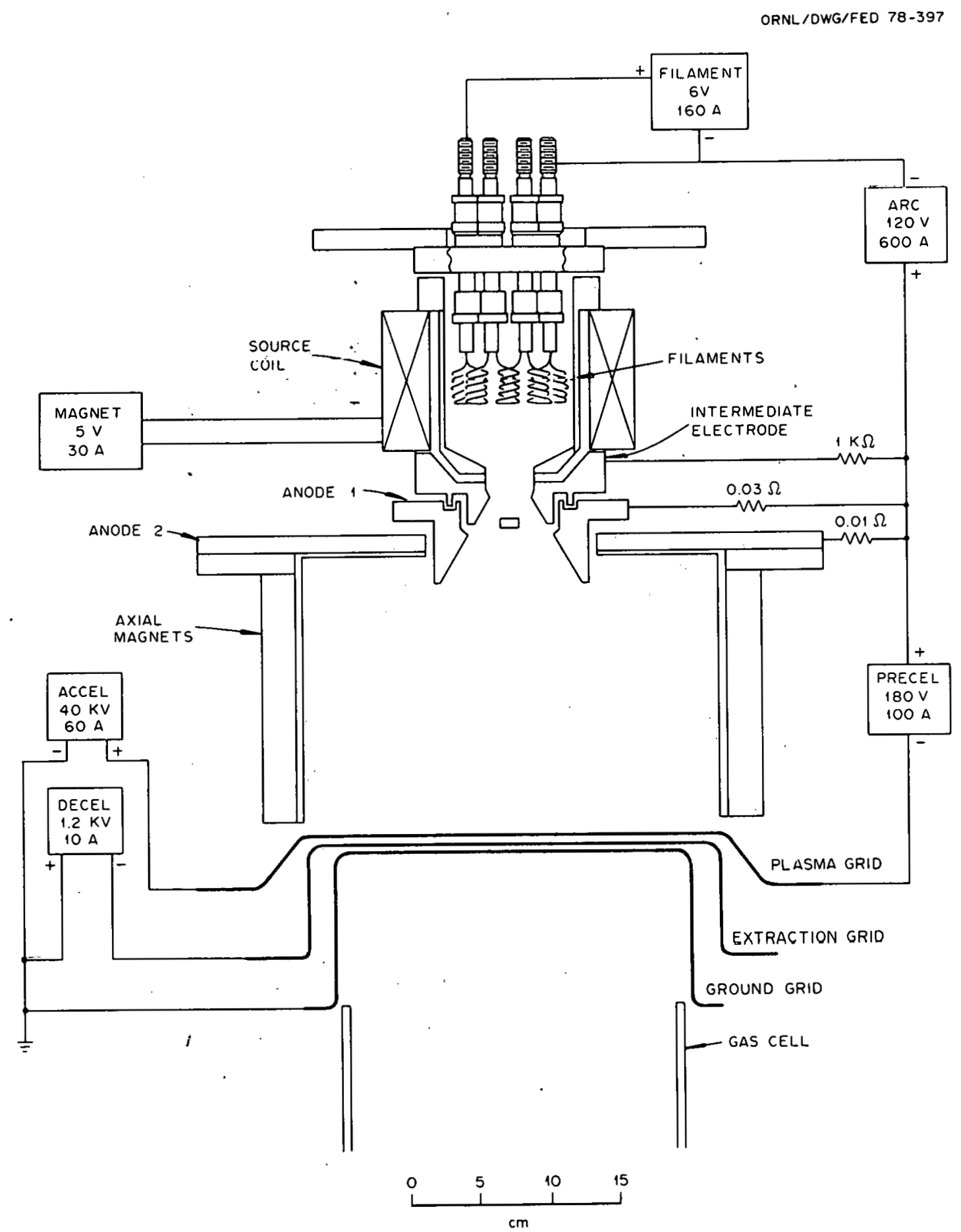

Fig. 2.2. Schematic representation of the ion source. 


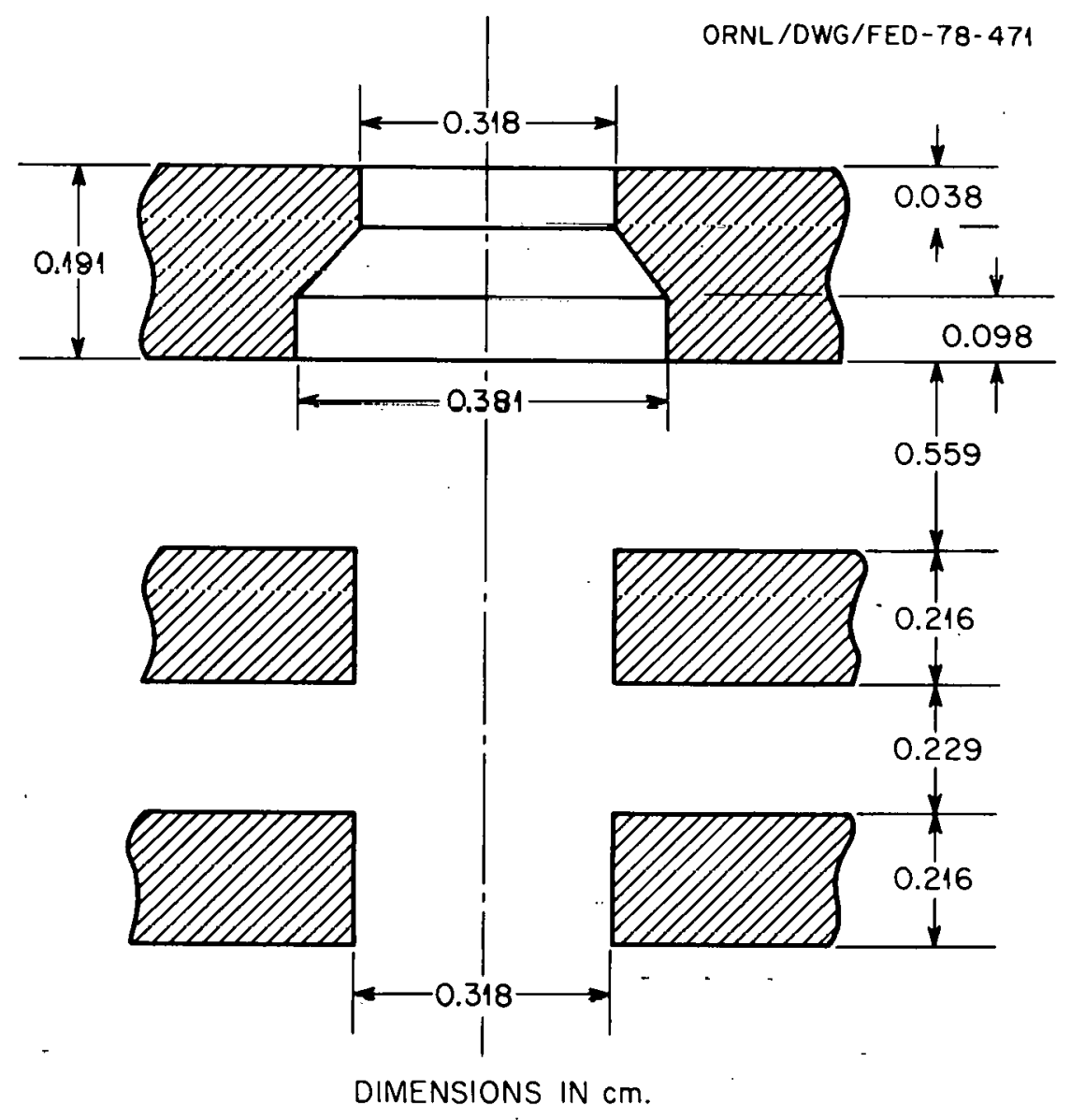

Fig. 2.3. Details of the shaped aperture. 


\subsection{BEAM TRANSPORT SYSTEM}

The ion beam extracted from the source is neutralized in a 1-m-long gas cell closely coupled to the source. The pressure at the end of the gas cell is maintained below $10^{-4}$ torr at gas throughputs of about 15 torr-1iters/sec using a cryocondensation pump with a pumping speed of $\sim 5 \times 10^{5}$ liters/sec. The unneutralized portion of the beam is magnetically diverted to ion dumps made of water-cooled swirl tubes. The magnetizing current required for different energy levels is shown in Fig. 2.4. A retractable swirl tube calorimeter capable of dissipating about 2 MW of power is positioned beyond the magnet for beam diagnostics as well as high duty cycle conditioning. When the calorimeter is open, the beam passes through a $2-\mathrm{m}-1$ long drift tube $30 \mathrm{~cm}$ in diameter and enters the target chamber that simulates the tokamak. The drift tube entrance is provided with beam defining plates, the opening of which can be remotely controlled over the range of $15 \times 15 \mathrm{~cm}$ to $25 \times 25 \mathrm{~cm}$. A fixed aperture of $20 \times 25 \mathrm{~cm}$ that corresponds to the PLT beam entrance aperture is also provided at the drift tube exit. The distance from the exit grid to the $20 \times 25 \mathrm{~cm}$ aperture is $4.1 \mathrm{~m}$, as opposed to $3.7 \mathrm{~m}$ at the PLT facility. Thus, the acceptance angle for the PLT machine is about $20 \%$ higher than that afforded at the test facility. The target chamber is pumped by a $2 \times 10^{5}$ liters/sec cryocondensation pump. The power flow results that are reported are obtained with the drift tube entrance aperture limited to $15 \times 15 \mathrm{~cm}$. The target chamber is provided with a retractable inertial target and a swirl tube target for beam diagnostics and power measurements. The power flow along the beam line is monitored using the flow rate and the temperature rise of the cooling water that circulates through each of the different elements. A PDP-11/40 computer is used for collecting the data. With the exception of the drift tube, the deflection magnet pole pieces, and a short $(\approx 10 \mathrm{~cm})$ isolation valve section located $20 \mathrm{~cm}$ downstream from the exit grid of the source, the power dissipation can be monitored on all the components where beam interception occurs. 


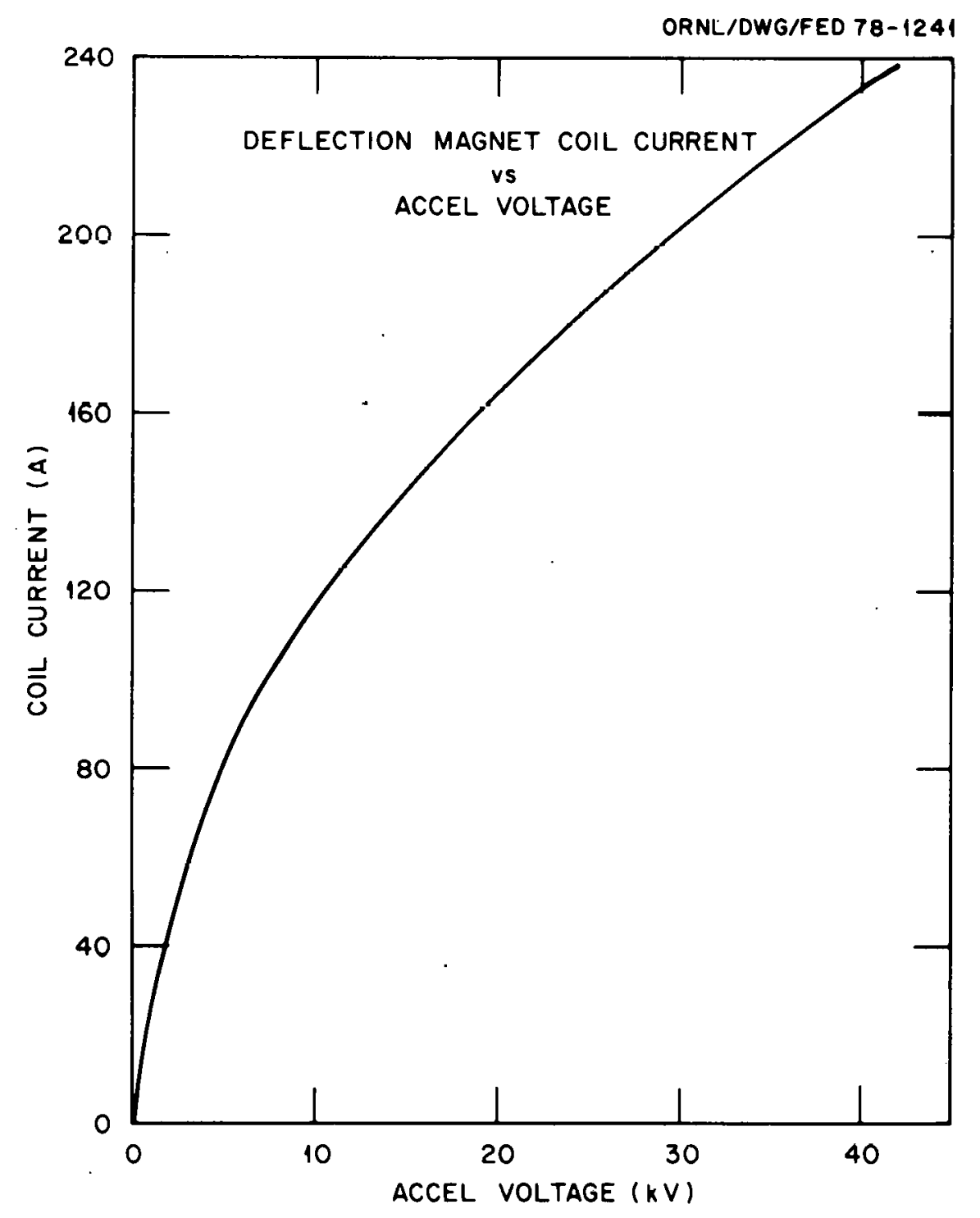

Fig. 2.4. The magnet current vs energy for hydrogen beam. 


\section{OPERATIONAL PROCEDURE}

\subsection{FILAMENT CONDITIONING}

The filaments are rated at $40 \mathrm{~A}$ each. The eight filaments are connected in four parallel sections, each consisting of two filaments in series. Thus, the filament supply current at the rated level will be $160 \mathrm{~A}$.

To avoid gross contamination of the source by the thermal decomposition products (water vapor, organic binding agent, etc.), the filaments should be partially conditioned under rough vacuum prior to being mounted on the source. To do this, gradually increase the current through each filament to about $30 \mathrm{~A}$, maintaining the pressure below 500 mtorr. After the gas evolution is complete, turn off the heating current and allow the filaments to cool down before installing them in the source.

The second phase of filament conditioning is done at the beam line. Slowly increase the heating current, maintaining the pressure at the end of the gas cell below $10^{-5}$ torr. Occasionally purge the intermediate electrode region with pure hydrogen. At each setting of the heating current, wait until the pressure starts dropping before increasing the heating current. Gradually increase the heating current to the full $160 \mathrm{~A}$.

\subsection{ARC DISCHARGE CONDITIONING}

Using the intermediate electrode gas feed only, bring the beam line box pressure for $\mathrm{dc}$ gas feed to about $5 \times 10^{-5}$ torr. Set the source magnet coil current to about $35 \mathrm{~A}$. Delay the arc pulse by about $100 \mathrm{msec}$ with respect to the gas pulse. Select an arc duration of $100 \mathrm{msec}$. Gradually raise the arc voltage until the arc strikes. This should happen at about $70 \mathrm{~V}$; the corresponding arc current will be 100-200 A. A check with the waveforms of anodes 1 and 2 will reveal if arc breakdowns are occurring. Before raising the arc current level, make sure that the arc inhibit circuit is functioning to avoid coating the insulators with metal vapor. Scan the source coil current from about $25 \mathrm{~A}$ 
to 50 A while avoiding repeated breakdowns. Step by step (about $5 \mathrm{~V}$ each), increase the arc voltage and scan the source coil current at each step. After the arc current exceeds about $300 \mathrm{~A}$, introduce the anode 2 gas feed and reduce the intermediate electrode gas. Operate the source in the high arc impedance mode with low or moderate gas feed and arc voltage in the range of 90-120 V. Follow the procedure until the arc current is about $700 \mathrm{~A}$. At higher arc currents, the source magnet current may have to be increased to about $40 \mathrm{~A}$. Typical values at the fully conditioned level are given below.

$$
\begin{array}{ll}
\text { For } \mathrm{H}_{2} \text { operation: } & \mathrm{I}_{\mathrm{a}_{1} \cong 200-250 \mathrm{~A}} \\
& \mathrm{I}_{\mathrm{a}_{2}} \cong 400-500 \mathrm{~A} \\
& \mathrm{v}_{\mathrm{arc}} \cong 110 \mathrm{~V} \\
\text { For } \mathrm{D}_{2} \text { operation: } & \mathrm{I}_{\mathrm{a}_{1}} \cong 250-300 \mathrm{~A} \\
& \mathrm{I}_{\mathrm{a}_{2}} \cong 500-600 \mathrm{~A} \\
& \mathrm{v}_{\mathrm{arc}} \cong 100 \mathrm{~V}
\end{array}
$$

\subsection{EXTRACTION CONDITIONING}

The last phase of the conditioning, the conditioning of the extraction electrodes to the full voltage and current-levels, should be done as follows.

Maintaining the lowest stable arc current $(\approx 100 \mathrm{~A})$, bring the accel voltage to its lowest level $(\approx 10 \mathrm{kV})$. Make sure that the decel inhibit is operational and that the accel pulse appears about $10 \mathrm{msec}$ before the arc discharge strikes. Keep the discharge duration to about $100 \mathrm{msec}$. Attempt extraction by switching on the decel voltage (set at about $1-1.5 \mathrm{kV})$. If the grids have been assembled with care, after a few breakdowns clean beam pulses should be obtained. During the initial stage of conditioning, the pulse repetition rate could be one every 2-4 sec. Gradually raise the voltage level. At each setting wait until about half a dozen clean pulses are obtained before changing the setting. As the voltage is increased, a stage will be reached characterized by 
constant breakdowns, due to serious mismatch in perveance (under-dense condition). This situation can normally be identified by breakdowns occurring at the beginning of the pulse. Lower the voltage level slightly to obtain stable beam pulses. Start raising the arc current to obtain higher beam current levels. As the current is increased, a point will be reached followed by constant breakdowns (over-dense condition). This is normally characterized by breakdowns at the end of the pulse if the power supply voltage exhibits a sag with time. Lower the arc current to obtain a stable beam and proceed by increasing the accel voltage. As the drain power exceeds about $500 \mathrm{~kW}$, decrease the pulse repetition rate to one every $10 \mathrm{sec}$.

During the extraction, it is necessary to adjust the three gas feeds (intermediate electrode, anode 2, and gas cel1) and the source magnet current quite carefully. Typically, at the higher power levels, the gas throughput is more or less evenly divided between the three gas feeds. It is important to note that to ensure proper operation and to obtain high arc efficiency, the gas feeds and the source magnet current need to be adjusted quite judiciously. The intermediate electrode gas feed has the most effect on the arc behavior. If the beam current pulse shows a hump in the rising end, it is quite likely due to too much gas feed. Similarly, if the beam current pulse shows a rising trend with time, it can be flattened by increasing the gas feed. For high arc efficiency it is better to reduce the gas, particularly the intermediate electrode gas, to a minimum. At higher current levels, it is necessary to increase the gas feed from anode 2 and the neutralizer. Note that the neutralizer gas feed also affects the source performance apart from serving its primary function of providing an equilibrium gas cell.

The source magnet current also needs to be adjusted with care. It has been mentioned in the arc conditioning procedure (Sect. 3.2) that the source magnet current should be scanned from 20 to $50 \mathrm{~A}$. During extraction it is preferable to start at about $30 \mathrm{~A}$. As the source current is brought up to its full value, it will be advantageous to gradually bring the source coil current to about $40 \mathrm{~A}$.

When the source is intended for operation at a certain level, it is better to condition the source to somewhat higher levels prior to 
operation. This will improve the reliability considerably. For example, if the source is conditioned to $42 \mathrm{kV}, 63 \mathrm{~A}$, it will operate with a high degree of reliability $(>90 \%)$ at about $40 \mathrm{kV}, 60 \mathrm{~A}$.

\section{CHARACTERISTICS OF THE SYSTEM}

In this section, some typical results showing the power deposition on various elements of the beamline are given. For these measurements, the target was located $4.1 \mathrm{~m}$ downstream from the exit grid. Thus the acceptance angle for the target was about $20 \%$ smaller than that of the PLT machine opening. However, these results do not reflect any reionization losses occurring in the drift tube. Note that the defining plates at the drift tube entrance were set at $15 \times 15 \mathrm{~cm}$.

Figure 4.1 shows the power deposition as a function of perveance under normal operation. Figure 4.2 shows the effect of applying a precel voltage on power transmission and beam optics. An improvement of about $30 \%$ in transmission efficiency, accompanied by a small decrease in optimum perveance, can be seen in the figure. Figure 4.3 is similar to Fig. 4.1 except that the perveance is varied by keeping the energy constant. In this way all the grid loadings can be plotted as a function of perveance. Figure 4.4 shows the "fine tuning effect" of the decel voltage (the target power shown is the neutral power). A gain of about $10 \%$ in power transmission can be achieved by careful control of the decel voltage. Figure 4.5 shows the power deposition characteristics when the plasma grid.with straight circular apertures was replaced by a shaped aperture grid. Finally, a typical plot of the species yield (measured at the ion dumps) is shown in Fig. 4.6. The measurement was made by scanning the deflection magnet coil current and noting the calorimetric signal from a single water-cooled swirl tube placed in the middle of the medium energy ion dump. The area under the curve shows a proton yield of about $91 \%$ at the dump, or better than $85 \%$ at the source exit grid. Very similar yields have been obtained with deuterium. 


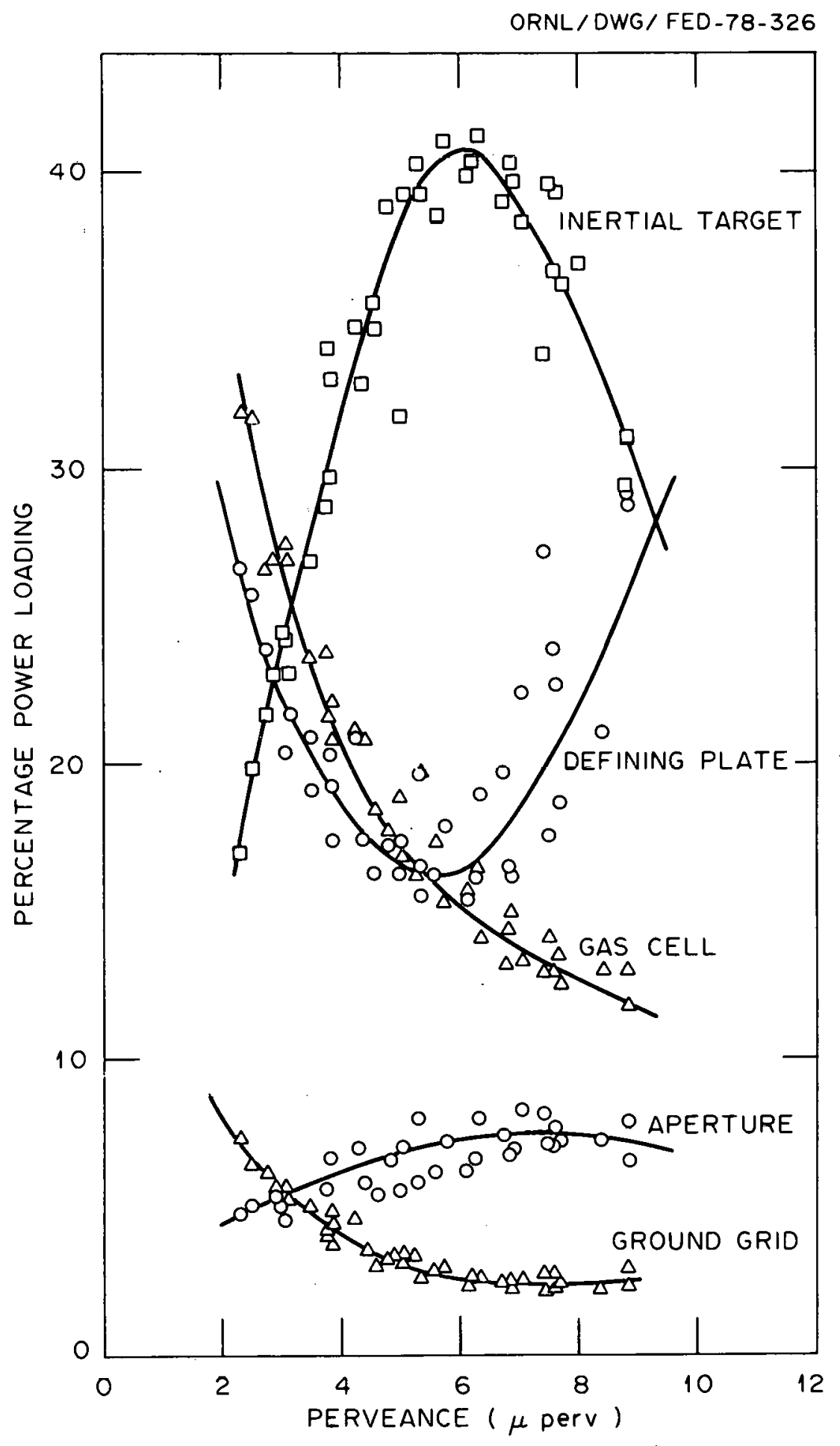

Fig. 4.I. Power deposition vs perveance without precel. 


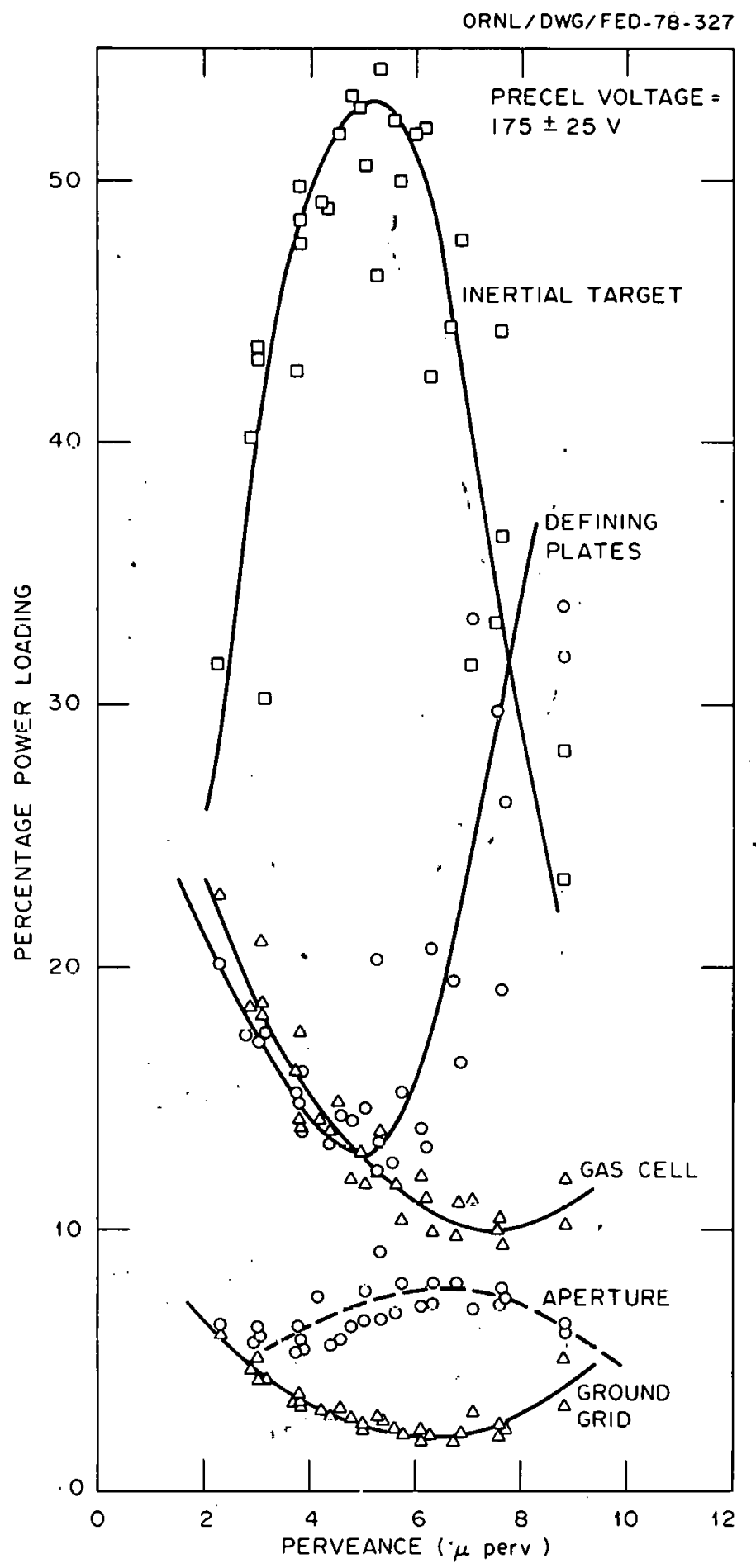

Fig. 4.2. Power deposition vs perveance with precel. 


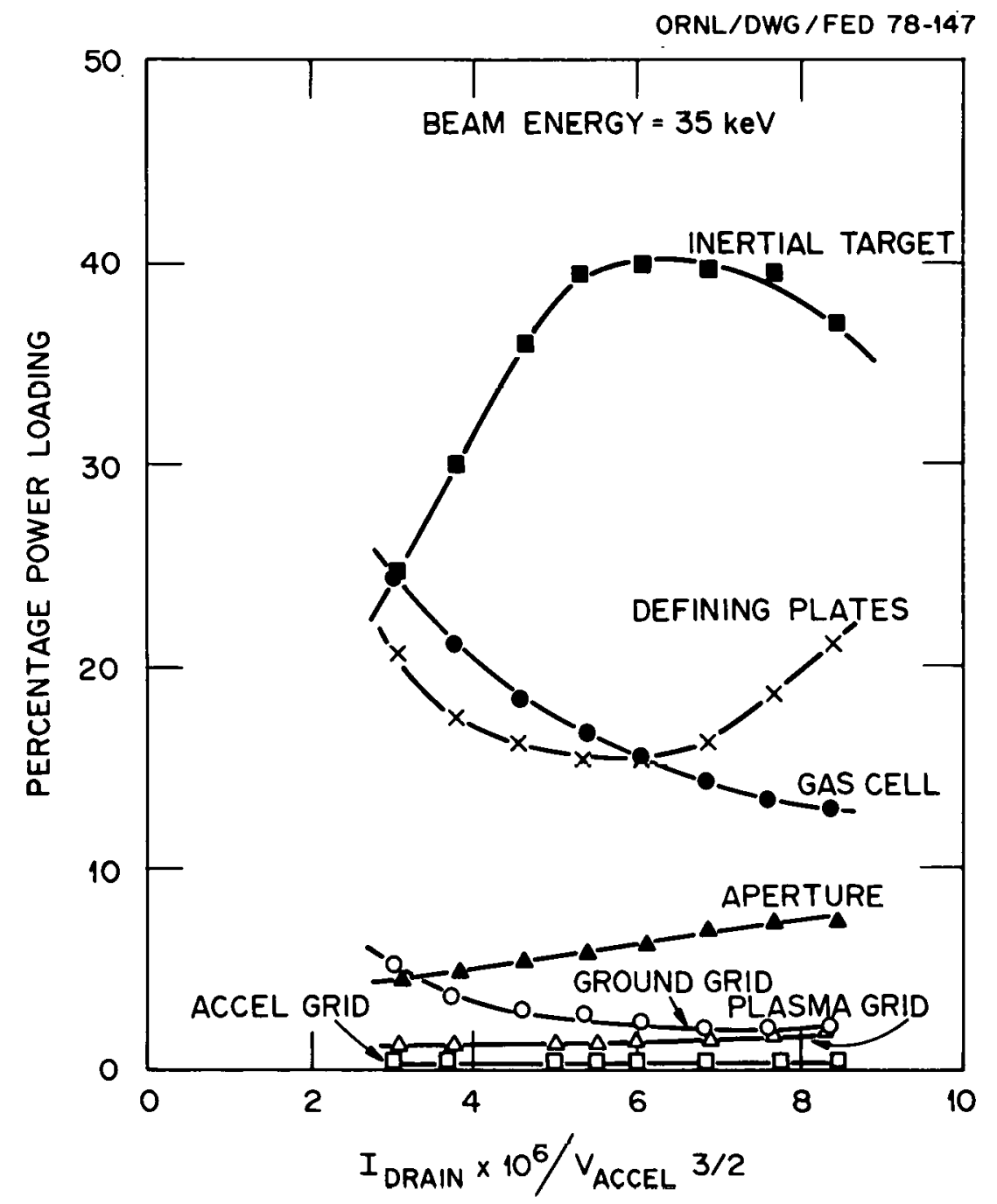

Fig. 4.3. Power deposition vs perveance at constant energy. 


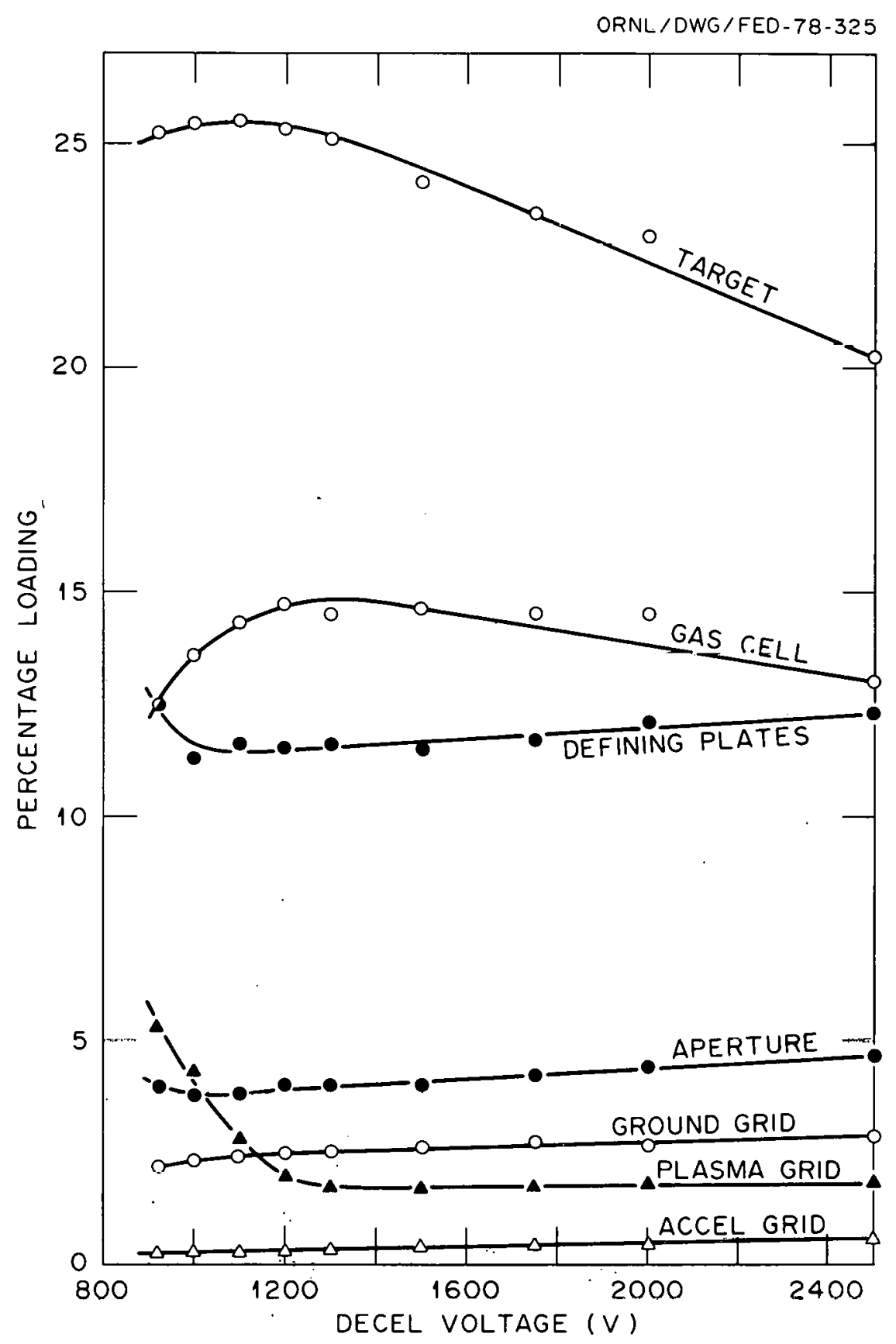

Fig. 4.4. Effect of varying the decel voltage on power deposition. 


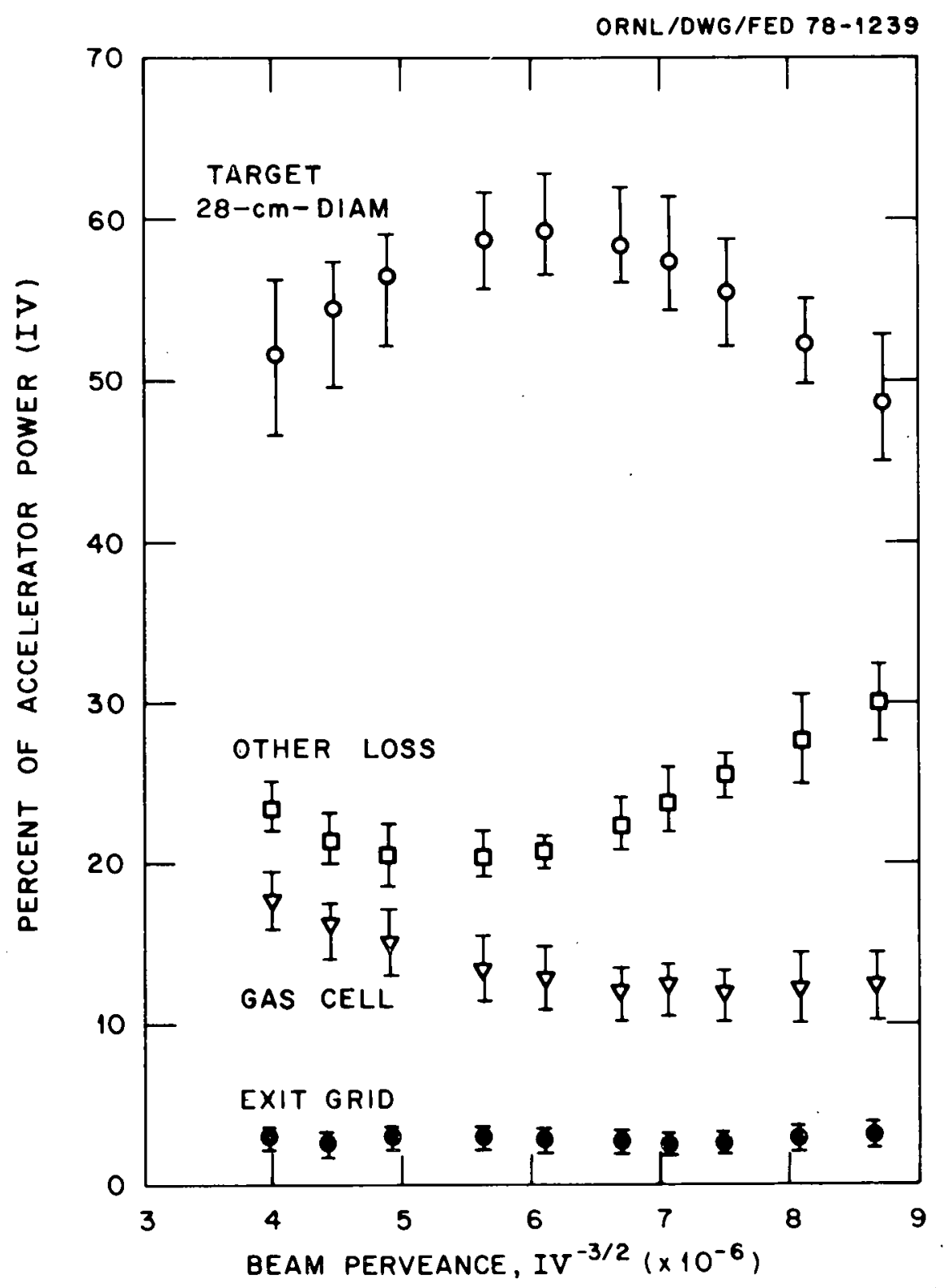

F1g. 4.5. Power deposicion characteristics with shaped aperture grid. 


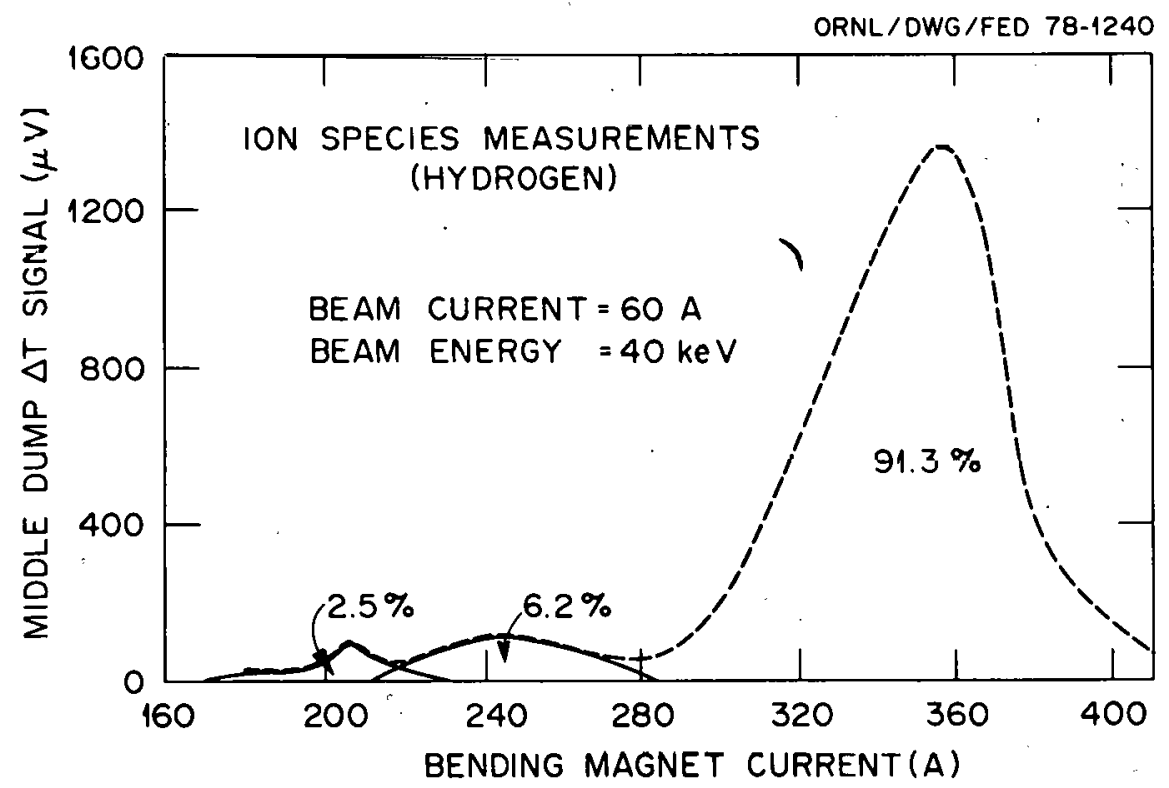

Fig. 4.6. Peaks corresponding to the three energy species. 


\section{TROUBLESHOOTING}

While it is difficult to pinpoint all possible causes for the malfunctioning of the source, some of the problems that we have encountered, identified, and rectified are outlined below. It is assumed that the source is assembled clean, the filaments are healthy, and the electrical connections to the source are proper.

1. Arc conditioning is difficult. Numerous arc breakdowns occur, particularly at the higher arc current levels ( $>400 \mathrm{~A}$ ).

This situation could be due to small air leaks into the source. Air leaks into the intermediate electrode region are particularly bad in this respect. Impurities introduced through the gas feed lines can also create this problem. It is recommended that stainless steel tubes, thoroughly cleaned prior to installation, be used as gas feed lines. Prior to operation, evacuate the entire gas feed line using the beam line cryopump. Pumping the gas line with small mechanical pumps is not recommended. Insulators coated by metal vapor resulting from repeated arc breakdowns can also make arc operation difficult. Make sure that the arc inhibit circuit functions normally prior to arc conditioning.

2. Arc runs reliably but arc efficiency is very low $(<1 \mathrm{~A} / 1.5 \mathrm{~kW})$. Improper gas feed and/or source magnetic field can cause this problem. Make sure that the gas is fed from the intermediate electrode, anode 2 , and the neutralizer. The total gas fed should be just sufficient for the proper beam current waveform. Set the magnet current between 35 and $42 \mathrm{~A}$. The plasma uniformity will be adversely affected if the magnet current is too different from this value. Reduce the intermediate electrode gas to a minimum while feeding more gas from the anode 2 side if needed. Leave the neutralizer gas to satisfy the equilibrium cell condition.

If even after readjusting the gas feed and the source field, the source continues to operate with poor arc efficiency, the permanent magnets need to be checked for proper polarities. Using a gauss meter, make sure that alternate magnets have the same polarity. In this connection, obtaining a pinhole image of the emission surface would be a very useful diagnostic technique. 
3. Source operation is normal except for poor beam transmission efficiency.

Cross-check with the power deposition data to identify grossly misaligned grids, missteered beam, nonequilibrium gas ce11, etc. The optimum perveance value would also reveal whether the grid spacing is set correctly.

4. Arc runs reliably but high voltage conditioning is difficult.

This is normally the result of severe electrode contamination or the presence of field enhancing objects in the interelestrnite region. If no improvement is found after repeated attempts, the source needs to be taken apart for closer examination of the electrodes. Note that too small $(<0.8 \mathrm{kV})$ or too large $(>5 \mathrm{kV})$ a decel voltage can also make extraction of the beam very difficult. It is recommended that the decel voltage be kept between 1 and $2 \mathrm{kV}$; the lower value gives the highest transmission efficiency.

\section{HISTORY OF ISX SOURCE 1}

The importance of adhering to the operational details specified in the report is illustrated by the following example.

During July 1978, PLT achieved record ion temperatures ( $>5 \mathrm{keV}$ ) by injecting $2.1 \mathrm{MW}\left(\mathrm{D}^{0}\right)$ into a hydrogen plasma. This power was contributed by four injectors, one of which (PL'l source 4) was producing only $350 \mathrm{~kW}$ of neutrals, well below its designated capacity. In order to boost the injected power, PLT source 4 was replaced by source 1 from the Impurity Study Experiment (ISX), which had delivered, in tests at ORNL, $830 \mathrm{~kW}\left(\mathrm{H}^{0}\right)$ to a $\pm 2^{\circ}$ half-angle target. However, at Princeton ISX source 1 could be made to deliver only about $650 \mathrm{~kW}\left(D^{0}\right)$ to the PLT plasma. We feel that the discrepancy resulted from a change in the operation mode of the plasma generator. For instance, operating the source magnet current above $50 \mathrm{~A}$ can degrade the plasma uniformity severely. The need for properly distributing the gas feed is of paramount importance, and gas purity is another essential consideration.

After the source was returned to ORNL, the electrode surfaces of the plasma generator were found to be severely discolored, suggesting an 
impurity problem. The result of a chemical analysis of the discolored surface is shown in the Appendix.

After the surfaces were cleaned, the source was reassembled with a fresh electron feed system (anode 1, intermediate electrode, and filament assembly). The plasma generator was conditioned to $100 \mathrm{~V}, 600 \mathrm{~A}$ within about two hours. However, extraction was extremely difficult (even at $10-\mathrm{kV}, 5-\mathrm{A}$ levels) and the source was found to favor high source magnet currents $(>45 \mathrm{~A})$. Yet after about five hours it was possible to make the source operate reliably at proper magnet currents $(<40 \mathrm{~A})$ at $35-\mathrm{kV}$, $40 \mathrm{~A}-1$ levels - and after a further 15 hours it was possible to fully condition the source.

The main point of this example is that the modified duoPIGatron source can be made to operate in a wide range of gas feed and source field conditions. Nevertheless, for the best performance of the source and for maximum power transmission, it is necessary to operate the source in the proper mode, as prescribed in this report. 
THIS PAGE

WAS INTENTIONALLY

LEFT BLANK 


\section{APPENDIX \\ COATINGS ON ALUMINUM RING}

J. C. Franklin

We analyzed material from the coating on the edge of the opening in the large ring, from the small dots in the groove, and from the Mo dish. All three samples were contaminated with $\mathrm{Na}, \mathrm{Cl}$, and $\mathrm{K}$, which $\mathrm{I}$ consider to be due to handling of the parts. All three areas contained the same metallic elements that are not a part of the Al alloy.

\begin{tabular}{llll} 
& Center ring & Dots & Larger ring \\
\cline { 2 - 3 } & 0.033 & 1 & 0.1 \\
$\mathrm{Ba}$ & 0.033 & 1 & 0.01 \\
$\mathrm{Cu}$ & 1.00 & 1.00 & 1.00 \\
$\mathrm{Fe}$ & 0.24 & 1 & 0.1 \\
$\mathrm{La}$ & 0.02 & 0.1 & 0.001 \\
$\mathrm{Mo}$ & 0.03 & $<0.1$ & 0.01 \\
$\mathrm{~Pb}$ & 0.0006 & $<0.1$ & 0.003 \\
$\mathrm{Si}$ & 0.4 & 3 & 0.03 \\
$\mathrm{Sr}$ & 0.03 & 0.7 & 0.01 \\
$\mathrm{Ti}$ & 0.006 & 0.3 & 0.003 \\
$\mathrm{~W}$ & 0.003 & $<0.1$ & 0.001
\end{tabular}

The data reported are semiquantitative atom ratios within a $f 11 \mathrm{~m}$. The fact that the $\mathrm{Cu}=1.00$ does not imply that the quantity of $\mathrm{Cu}$ in each film is equal but means that $\mathrm{Cu}$ was a major component in each film. No organics could be detected. 
THIS PAGE

WAS INTENTIONALLY

LEFT BLANK 
ORNL/TM-6658

Dist. Category UC-20

\section{INTERNAL DISTRIBUTION}

38. H. Postma

39. M. W. Rosentha1

40. P. M. Ryan

41. D. E. Schechter

42. S. W. Schwenterly

43. J. Sheffield

44. D. Steiner

45. W. L. Stirling

46. C. C. Tsai

47. J, H, Whealton

48. R. E. Wright

49-50. Central Research Library

51. Document Reference Section

52-53. Laboratory Records Department

54. Laboratory Records, ORNL-RC

55. ORNL Patent Office

56. Fusion Energy Division Library

57. Fusion Energy Division

Communications Center

EXTERNAL DISTRIBUTION

58. D. J. Anthony, General Electric Co., Bldg. 23, Rm. 290, 1. River Rd., Schenectady, NY 1.2345

59. C. C. Baker, Argonne National Laboratory, 9700 S. Cass Ave., Argonne, IL 60439

60. K. H. Berkner, Lawrence Berkeley Laboratory, University of California, Berkeley, CA 94120

61. Director, Centre d'Etudes Nucleaires, B.P. No. 6, Fontenayaux-Roses, France

62. J. F. Clarke, Office of Fusion Energy, Department of Energy, Washington, DC 20545

63. A. Colleraine, General Atomic Co., P.0. Box 608, San Diego, CA 92112

64. R. W. Conn, Department of Nuclear Engineering, University of Wisconsin, Madison, WI 53706

65. W. S. Cooper, Lawrence Berkeley Laboratory, University of California, Berkeley, CA 94120

66. S. 0. Dean, Office of Fusion Energy, Department of Energy, Washington, DC 20545

67. H. Eubank, Plasma Physics Laboratory, Princeton University, P.0. Box 451, Princeton, NJ 08540

68. J. A. Fasolo, Argonne National Laboratory, 9700 S. Cass Ave., Argonne, IL 60439 
69. H. K. Forsen, Exxon Nuclear Co., Inc., 777 106th Ave., N.E., Bellevue, WA 98009

70. T. K. Fowler, Lawrence Livermore Laboratory, University of California, P.0. Box 808, Livermore, CA 94551

71. H. P. Furth, Plasma Physics Laboratory, Princeton University, P.0. Box 451, Princeton, NJ 08540

72. M. Gottlieb, Plasma Physics Laboratory, Princeton University, P.0. Box 451, Princeton, NJ 08540

73. R. W. Gould, California Institute of Technology, Mail Stop 116-81, Pasadena, CA 91125

74. L. R. Grisham, Plasma Physics Laboratory, Princeton University, P.0. Box 451, Princeton, NJ 08540

75. R. L. Hirsch, Exxon Research and Engineering Co., P.0. Box 101, Florham Park, N.T 07932

76. E. B. Hooper, Lawrence Livermore Laboratory, University of California, P.0. Box 808, Livermore, CA 94551

77. R. Huse, Chairman, EPRI Fusion Program Committee, Public Service Electric and Gas Co., 80 Park Place, Newark, NJ 07101

78. E. Kintner, Office of Fusion Energy, Department of Energy, Washington, DC 20545

79. W. Kunke1, Lawrence Berkeley Laboratory, Un1versity of California, Berkeley, CA 94120

80. A. R. Martin, Culham Laboratory, Abingdon, Oxfordshire OX14 3DB, United Kingdom

81. S. Matsuda, Japan Atomic Energy Research Institute, Tokai, Ibaraki, Japan

82. Director, Max-Planck-Institut für Plasmaphysik, Garching bei Munchen, Federal Republic of Germany

83. G. H. Miley, Nuclear Engineering Program, University of Illinois, Urbana, IL 61801

84. A. W. Molvik, Lawrence Livermore Laboratory, University of California, P.0. Box 808, Livermore, CA 94551

85. T. Ohkawa, General Atomic Co., P.0. Box 608, San Diego, CA 92112

86. J. Osher, Lawrence Livermore Laboratory, University of California, P.0. Box 808, Livermore, CA 94551

87. B. Outten, Western Metal Products Co., 1300 Weber St., Orlando, FL 32803

88. K. Prelec, Brookhaven National Laboratory, Upton, Long Island, NY 1.1 .973

89. B. Pritchard, Plasma Physics Laboratory, Princeton University, P.0. Box 451, Princeton, NJ 08540

90. R. V. Pyle, Lawrence Berkeley Laboratory, University of California, Berkeley, CA 94120

91. G. Schilling, Plasma Physics Laboratory, Princeton University, P.0. Box 451, Princeton, NJ 08540

92. N. N. Semasko, Kurchatov Atomic Energy Institute, Moscow, U.S.S.R.

93. Th. Sluyters, Brookhaven National Laboratory, Upton, Long Island, NY 11973

94. L. D. Stewart, Plasma Physics Laboratory, Princeton University, P.0. Box 451, Princeton, NJ 08540 
95. D. R. Sweetman, Culham Laboratory, Abingdon, Oxfordshire ox14 3DB, United K1ngdom

96. E. Thompson, Culham Laboratory, Abingdon, Oxfordshire OX14 3DB, United Kingdom

97. M. Ulrickson, Plasma Physics Laboratory, Princeton University, P.0. Box 451, Princeton, NJ 08540

98. F. Valckx, Centre d'Etudes Nucleaires, B.P. No. 6, Fontenay-auxRoses, France

99. J. M. Williams, Office of Fusion Energy, Department of Energy, Washington, DC 20545

100. Office of Assistant Manager, Energy Research and Development, Department of Energy, Oak Ridge Operations, P.O. Box E, Oak Ridge, TN 37830

101-222. Given distribution as shown in TID-4500, Magnetic Fusion Energy (Distribution Category UC-20) 